\title{
LAZER E SOCIABILIDADE DOS ALUNOS COM DOENÇA FALCIFORME
}

\author{
Gabriela Silva Santos'; ${ }^{1}$ Ivanilde Guedes de Mattos $^{2}$ \\ 1. Bolsista PIBIC/FAPESB, Graduanda em Educação Física, Universidade Estadual de Feira de Santana, e-mail: \\ gabrielasantosaa@gmail.com \\ 2. Orientadora, Departamento de saúde, Universidade Estadual de Feira de Santana, e-mail: \\ ivyfirmina@gmail.com
}

PALAVRAS-CHAVE: falciforme; educação física; saúde.

\section{INTRODUÇÃO}

Apesar da Doença Falciforme (DF), aqui compreendida como anemia e o traço falciforme, atingir muitos brasileiros, afetando principalmente o estado da Bahia que, segundo o Ministério da Saúde possui 1:650 nascidos vivos acometidos pela doença por ano, os falcêmicos ainda são altamente invisibilizados e a doença pouco conhecida. A DF pode ser definida como uma modificação genética que, ao invés do indivíduo produzir a hemoglobina A, produz a hemoglobina S. Para que a anemia falciforme aconteça é necessário que a pessoa receba dois genes $\mathrm{S}$ (um do pai e outro da mãe). Caso ocorra o recebimento de um gene $\mathrm{S}$ e outro gene A, o indivíduo desenvolve apenas o traço falciforme. Compreendendo as circunstâncias da DF, é importante que o profissional de Educação Física (EF) atuante na escola se preocupe com a inclusão de todos os alunos em suas aulas. Para isso, é necessário que haja um conhecimento prévio do que é a DF e sobre até que ponto a atividade física é saudável para os falcêmicos. A não participação efetiva dessas crianças nas aulas de EF escolar pode vir a acarretar discriminação. Por outro lado, a participação de forma indevida e com alta intensidade invariavelmente poderá agravar os sintomas. Desse modo, trazemos para essa discussão a perspectiva do lazer, aqui compreendida como elemento necessário na vida de todos e especialmente para as crianças falcêmicas. A presente pesquisa se preocupa em responder algumas questões: Como se dá a participação desses alunos nas aulas de EF? Como essas crianças se percebem e interagem nos espaços de lazer de Feira de Santana- BA?

\section{MATERIAIS E MÉTODOS}

\section{Desenho do estudo}

A investigação é uma pesquisa de campo, de corte transversal e abordagem quantitativa que pode ser definida como:

Em termos gerais, propomos que a ideia de quantificação abrange um conjunto de procedimentos, técnicas e algoritmos destinados a auxiliar o pesquisador a extrair de seus dados subsídios para responder à(s) pergunta(s) que o mesmo estabeleceu como objetivo(s) de trabalho. (FALCÃO, RÉGNIER, 2000, P.232)

\section{Caracterizando o espaço e sujeito da pesquisa}

A pesquisa é feita com crianças a partir de oito anos, inseridas nas escolas da rede pública e privada de Feira de Santana- BA.

$\mathrm{O}$ espaço em que a coleta de dados aconteceu foi o Centro de Referência às pessoas com anemia falciforme, localizado no CSU, em Feira de Santana - BA. 
Antes de iniciarmos a coleta de dados, foi submetido à Secretaria Municipal de Saúde de Feira de Santana - Seção de Capacitação Permanente, um pedido de autorização que foi aceito pela sua coordenadora, a $\mathrm{Sr}^{\mathrm{a}}$ Ariella Covas.

\section{Instrumentos de Coleta de Dados}

Os instrumentos utilizados para a coleta de dados foram:

1- O termo de consentimento institucional supracitado encaminhado para $\operatorname{Dr}^{\mathrm{a}}$ Ana Cristina Franqueira e para $\operatorname{Dr}^{\mathrm{a}}$ Luciana Brito, responsáveis pela Divisão de Enfermagem do CSU, no programa de Anemia Falciforme.

2- Termo de Consentimento Livre e Esclarecido (TCLE) encaminhado aos pais e/ou responsáveis dos participantes da pesquisa.

3- Termo de Assentimento Livre e Esclarecido (TALE) encaminhado aos participantes da pesquisa. Esse documento foi necessário por se tratar de menores de 18 anos.

4- Questionário auto-aplicado estruturado previamente e encaminhado aos participantes da pesquisa.

\section{Procedimento para coleta de dados}

Foram feitas visitas ao Centro de Referência às pessoas com anemia falciforme, onde as famílias tomaram conhecimento da presente investigação e os questionários foram aplicados de acordo à prévia autorização dos pais e/ou responsáveis e dos participantes.

\section{Procedimento para análise de dados}

Após todos os questionários aplicados, os dados foram analisados através das técnicas de estatística descritiva, considerando a frequência das respostas obtidas. Os questionários respondidos só foram acessados pelas pesquisadoras (bolsista e orientadora).

\section{DISCUSSÃO DE DADOS}

Como a DF já foi definida anteriormente, agora vamos nos ater a definição de lazer.

Falar de lazer se torna um desafio quando se reconhece algumas outras perspectivas que fogem do clichê lazer = tempo livre. Tomando como base Rosa (2006), o lazer pode ser definido com base em três elementos: Tempo, atitude e atividade.

O tempo é o elemento que talvez traga mais discussões. Muitos autores falam sobre o lazer se dar no tempo de não-trabalho, mas sem considerar outras obrigações como, por exemplo, obrigações familiares, religiosas e políticas. Dessa maneira, entendemos que a definição que mais se encaixe seja que o lazer é o tempo sem nenhuma imposição. Nesse sentido, Marcelino (2006) traz que o termo mais correto seria, então, tempo disponível. A atitude do sujeito se torna importante frente a esse tempo disponível. Em outras palavras, "o lazer seria resultado da expressão livre, criativa e satisfatória do sujeito". (Puig; Trilla apud Rosa, 2006, p. 17). O terceiro elemento, a atividade, também pode ser definidora do lazer. A atividade escolhida pelo indivíduo pode caracterizar ou não o lazer.

O que é lazer para uns, pode não ser para outros. No que diz respeito à realidade da criança, as atividades escolhidas geralmente são aquelas que trazem a elas a maior sensação de liberdade, onde elas podem se expressar gritando, correndo, pulando, etc., ou seja, coisas ligadas ao brincar. 
Esse brincar do qual tanto falamos não precisa na verdade ser definido, mas antes compreendido como uma atividade cheia de significados e necessária à criança, pois vai lhe proporcionar condições de compreensão do que é a vida. Para essa criança, brincar é um ato tão espontâneo e típico quanto comer, dormir, andar ou falar. É seu trabalho. (OLIVEIRA,2010,p.73)

Pensando na realidade das crianças com DF, essa brincadeira pode ser prejudicada por causa dos sintomas, principalmente as dores. A criança, por outro lado, não encontra dificuldades em modificar as brincadeiras para se encaixar à sua realidade. Apesar de todos os cuidados que devem ser tomados e toda a limitação que a doença traz, observando-as em campo pudemos perceber que entre elas não há essa separação estereotipada na qual esperamos.

Adentrando os dados levantados, consideramos alguns parâmetros como (1) Como se dá a participação dos alunos com DF nas aulas de EF escolar; (2) Em qual frequência essas crianças praticam atividade física, incluindo atividades de vida diária (AVDs) e (3) Como essas crianças se percebem e interagem nos espaços de lazer de Feira de Santana- BA.

Em seguida, na tabela apresentada, apresentaremos alguns dados levantados durante a aplicação do questionário com as crianças.

Tabela 1- Primeiros resultados

\begin{tabular}{|c|c|c|c|}
\hline Para ir à escola & $50 \%$ vão a pé & $\begin{array}{l}50 \% \text { vão } \mathrm{de} \\
\text { transporte público }\end{array}$ & - \\
\hline $\begin{array}{l}\text { Participação nas } \\
\text { aulas de Educação } \\
\text { Física }\end{array}$ & $\begin{array}{l}20 \% \text { participam das } \\
\text { aulas de EF }\end{array}$ & $\begin{array}{l}30 \% \text { participam às } \\
\text { vezes }\end{array}$ & $\begin{array}{l}50 \% \text { não têm aulas } \\
\text { de EF }\end{array}$ \\
\hline $\begin{array}{l}\text { Prática de atividade } \\
\text { física durante uma } \\
\text { semana típica }\end{array}$ & $\begin{array}{l}40 \% \text { praticam de } 1 \text { a } \\
3 \text { dias na semana }\end{array}$ & $\begin{array}{ll}20 \% & \text { praticam } \\
\text { diariamente }\end{array}$ & $\begin{array}{l}40 \% \text { não praticam } \\
\text { atividade física }\end{array}$ \\
\hline $\begin{array}{l}\text { Atividades } \quad \text { que } \\
\text { costumam } \\
\text { quando não estão na } \\
\text { escola }\end{array}$ & $\begin{array}{l}80 \% \text { ficam em casa } \\
\text { vendo } \mathrm{TV} \text {, jogando } \\
\text { vídeo game ou } \\
\text { acessando as redes } \\
\text { sociais }\end{array}$ & $\begin{array}{l}20 \% \text { vão ao } \\
\text { shopping, cinema, } \\
\text { teatro, etc. }\end{array}$ & - \\
\hline $\begin{array}{l}\text { Entre } \quad \text { espaços } \\
\text { públicos e privados }\end{array}$ & $\begin{array}{l}50 \% \text { vão apenas a } \\
\text { espaços públicos }\end{array}$ & $\begin{array}{l}50 \% \text { vão a espaços } \\
\text { públicos e privados }\end{array}$ & - \\
\hline Custeio do lazer & $\begin{array}{l}50 \% \text { afirmaram que é } \\
\text { caro se divertir na } \\
\text { cidade }\end{array}$ & $\begin{array}{l}30 \% \text { dizem não ser } \\
\text { caro }\end{array}$ & $\begin{array}{l}20 \% \text { admitiram não } \\
\text { saber }\end{array}$ \\
\hline $\begin{array}{l}\text { Lazer nos bairros } \\
\text { onde moram }\end{array}$ & $\begin{array}{l}30 \% \text { disseram que há } \\
\text { espaço de lazer }\end{array}$ & $\begin{array}{l}70 \% \text { disseram não } \\
\text { existir esse espaço }\end{array}$ & - \\
\hline
\end{tabular}

Fonte de pesquisa

São esses os dados que coletamos e que nos permite crer que é que a maioria das crianças não pratica atividade física ou praticam pouco, incluindo as AVDs. Apesar disso, 80\% delas afirmaram desejar praticar alguma atividade física. Nas respostas apareciam atividades como o ballet ou alguma outra modalidade de dança, natação e futebol. 
Sobre os espaços de lazer, nenhuma das crianças afirmou ir apenas a espaços privados. O que foi observado é que muitas das atividades desenvolvidas eram conjuntamente com seus pais. Alguns espaços foram citados, como parques públicos, piscinas (particulares ou clubes), shopping e, na maioria das vezes, casas de familiares. Concluímos então que, o lazer infantil está muito atrelado com a forma que seus responsáveis se divertem.

\section{CONSIDERAÇÕES FINAIS}

Os sintomas da DF são conhecidos e reconhecemos que precisa haver um cuidado com essas crianças. Apesar disso, nos inquietamos com a baixa mobilidade da Educação Física em integrá-las às manifestações corporais. O número baixo dessas crianças que praticam atividade física é preocupante e o fato de $50 \%$ delas nem terem aulas de EF nos afligem mais ainda. Nega-las o direito de conhecer essas manifestações corporais e reconhecer-se nesse processo é algo que deve ser interrompido. É necessário que haja maior mobilidade entre os profissionais da área de EF e é nesse sentido que trouxemos o trabalho, para que agora conheçamos um pouco mais sobre essa realidade e assim, nos aproximemos mais, sabendo que as limitações da doença não são suficientes para parar essas crianças.

O lazer traz consigo uma função muito maior do que simplesmente entreter ou ser o tempo oposto ao trabalho, como já desmistificamos aqui. O lazer garante uma interação, que traz mudanças tanto para a criança, como para o ambiente na qual ela está.

Nós, como profissionais de EF, reconhecemos e atestamos essa importância e desejamos que os municípios também reconheçam, trazendo mais opções para que todos possam se integrar, inclusive essas crianças com DF.

\section{REFERÊNCIAS}

BRASIL. Brasil. Secretaria de Saúde. Doença Falciforme. Disponível em: <http://portalsaude.saude.gov.br/index.php/o-ministerio/principal/secretarias/955-sas-raiz/dahuraiz/sangue-e-hemoderivados/12-sangue-e-hemoderivados/13335-doenca-falciforme>. Acesso em: 30 jul. 2017.

FALCÃO, Jorge Tarcísio da Rocha; RÉGNIER, Jean-claude. Sobre os métodos quantitativos na pesquisa em ciências humanas: riscos e benefícios para o pesquisador. Revista Brasileira de Estudos Pedagógicos, Brasília, v. 81, p.229-243, ago. 2000. Disponível em: <http://rbep.inep.gov.br/index.php/rbep/article/view/937/911>. Acesso em: 15 jul. 2017.

OLIVEIRA, Luciana da Silva de. Brincar(es) na infância: Possibilidades no contexto da doença falciforme e da hemofilia. 2010. 123 f. Dissertação (Mestrado) - Curso de Pós-graduação em Educação, Universidade Federal de Juiz de Fora, Juiz de Fora, 2010. Disponível em: <http://www.ufjf.br/ppge/files/2010/07/Dissertação-Luciana-da-S.-de-Oliveira.pdf>. Acesso em: 09 maio 2017.

ROSA, Tatiane da Silva da. Lazer: Concepções e vivências de uma juventude. 2006. 122 f. Dissertação (Mestrado) - Curso de Faculdade de Educação, Universidade Federal do Rio Grande do Sul, Porto Alegre, 2006. Disponível em: <http://www.lume.ufrgs.br/handle/10183/10316>. Acesso em: 17 jul. 2017. 